\title{
Effect of plastic catheter material on bacterial adherence and viability
}

\author{
G. LOPEZ-LOPEZ, A. PASCUAL* and E. J. PEREA
}

Department of Microbiology, School of Medicine, University of Seville, Apdo. 914, 41080-Seville, Spain

\begin{abstract}
Summary. The kinetics of adherence of single isolates of Staphylococcus aureus, S. epidermidis, Pseudomonas aeruginosa and Escherichia coli to catheters made of polyvinyl chloride (PVC), Teflon ${ }^{\circledR}$, siliconised latex, polyurethane and Vialon ${ }^{\circledR}$ was evaluated by a radiometric assay. Radiolabelled bacteria $\left(10^{8} \mathrm{cfu} / \mathrm{ml}\right)$ were incubated in vials containing $1-\mathrm{cm}$ lengths of catheter for up to 3 days. The peak of maximal adherence to each biomaterial was reached after $24 \mathrm{~h}$ for $P$. aeruginosa and after $72 \mathrm{~h}$ for the other strains. Bacterial adherence to PVC and siliconised latex was significantly higher $(2-6$ times; $p<0.05)$ than to the other biomaterials for all the strains. The lowest values of adherence were observed with polyurethane and Vialon ${ }^{\circledR}$ for the staphylococci but with Teflon ${ }^{\circledR}$ for E. coli and P. aeruginosa. Bacterial viability and growth was evaluated in eluates obtained from incubation of segments of each catheter in buffer for $24 \mathrm{~h}$. None of the eluates affected the viability of the staphylococci. However, all of them, significantly increased the growth of $E$. coli and $P$. aeruginosa with the exception of the eluate from siliconised latex, in which the inoculum count was reduced to an undetectable level for $E$. coli. We conclude that bacterial adherence to catheters may depend in part on the nature of the biomaterial and that certain substances eluted from the catheters may affect the viability and growth of different micro-organisms.
\end{abstract}

\section{Introduction}

Intravascular and urinary catheters are frequently used in hospitals. Several studies have demonstrated significant infection rates associated with local skin conditions, methods used in the placement of such devices and the duration of catheter usage ${ }^{1,2}$ Catheterassociated infections are a significant source of nosocomial morbidity and mortality. ${ }^{3}$ The mechanisms by which infections develop are not fully understood but the phenomenon of adherence to the biomaterials appears to be a critical factor in initiating colonisation and subsequent infection. ${ }^{4}$

The nature and chemical composition of the biomaterials commonly used to make medical devices differ, and many of them contain different additives and plasticisers to improve their physico-chemical properties and biocompatibility. ${ }^{5}$

The adherence of different micro-organisms to, and their survival in, catheters is promoted not only by bacterial factors but additional bacterium-device interactions could participate in this phenomenon. ${ }^{6}$ It has been proposed that some micro-organisms, e.g., coagulase-negative staphylococci, could metabolise some of the components of plastic catheters in the absence of other nutrients and use them to sustain growth on the surface of biomaterials. ${ }^{7}$

Received 3 May 1990; revised version accepted 9 Oct. 1990. *Correspondence should be sent to Dr A. Pascual.
We have developed an experimental in-vitro system for evaluating quantitatively the adherence of bacteria over a period of 3 days to five intravascular and urinary catheters composed of polyvinyl chloride (PVC), Teflon $^{\circledR}$, siliconised latex, polyurethane and Vialon ${ }^{\circledR}$. The effect of eluates of these biomaterials on the growth of different micro-organisms in the absence of other nutrient sources has also been assessed.

\section{Materials and methods}

\section{Bacterial strains and radioactive labelling}

One strain each of Escherichia coli (HUS 25), Pseudomonas aeruginosa (HUS 36), Staphylococcus aureus (HUS 41) and S. epidermidis (HUS 59) were used. The strains were isolated from blood cultures of patients with catheter-associated infections. Strains were identified by standard methods. Heavy suspensions of each strain in Tryptone Soy Broth (Oxoid) with glycerol $10 \%$ were stored in small volumes at $70^{\circ} \mathrm{C}$.

For adherence assays, several colonies from a nutrient-agar plate were inoculated into $5 \mathrm{ml}$ of Mueller-Hinton broth containing $\left({ }^{2-3} \mathrm{H}\right)$ adenine (specific activity $24 \mathrm{Ci} / \mathrm{mmol}$; Amersham) $10 \mu .^{8}$ Before use, bacteria were washed three times with phosphate-buffered saline (PBS) and resuspended to obtain a final concentration of $10^{8} \mathrm{cfu} / \mathrm{ml}$. 


\section{Catheters}

Catheters made of five different biomaterials were used: (a) polyvinyl chloride (PVC) (Drum-Cartridge ${ }^{\circledR}$ catheter, Abbott Laboratories, Eire); (b) Teflon ${ }^{(8)}$ (Abbocath R-T, Abbott Laboratories); (c) latex (siliconised) two-way paediatric Foley catheter (Inmed $^{\circledR}$; Inmed USA, Malaysia); (d) polyurethane (Cavafix Certo $^{\circledR}$; B. Braun Melsugen AG, Germany); and (e) Vialon ${ }^{\circledR}$ (Viacath $^{\circledR}$, Becton Dickinson, USA). For adherence assays, catheters were cut under sterile conditions into $1.0-\mathrm{cm}$ segments and pre-incubated in $10 \mathrm{ml}$ of sterile isotonic PBS at $37^{\circ} \mathrm{C}$ for $1 \mathrm{~h} .^{9}$

Eluates of the catheters were prepared by incubating 30 segments of each in $10 \mathrm{ml}$ of PBS at $37^{\circ} \mathrm{C}$ for $24 \mathrm{~h}$ under sterile conditions.

\section{Bacterial adherence to urinary catheters}

For the adherence assays, $10 \mathrm{ml}$ of radioactive bacterial suspension $\left(10^{8} \mathrm{cfu} / \mathrm{ml}\right)$ were incubated with 30 segments of each catheter type in $25-\mathrm{ml}$ screwcapped glass vials at $37^{\circ} \mathrm{C}$. After $5 \mathrm{~min}, 1,6,24$ and $72 \mathrm{~h}$, two catheter segments were removed, washed five times in cold PBS to remove all non-adherent bacteria and deposited in polypropylene vials. (Biovial $^{\circledR}$; Beckman Instruments, USA) with $2.5 \mathrm{ml}$ of scintillation fluid (Aqua Luma Plus, Lumac/3M, The Netherlands). Catheter-bound radioactivity was determined in a scintillation counter (1701 LS Beckman Instrument, Inc). From this value, the number of bacteria adherent per $\mathrm{cm}^{2}$ of catheter was calculated by dividing the number of bacteria adherent to a catheter piece by the total surface area of the piece. The relationship between radioactivity and number of bacteria was obtained by counting in a biovial $100 \mu \mathrm{l}$ of the initial inoculum.

\section{Bacterial growth in catheter eluates}

Each strain was inoculated into catheter eluates at a final concentration of $10^{3} \mathrm{cfu} / \mathrm{ml}$. At timed intervals, 10- $\mu$ l samples were diluted in ice-cold PBS and pour plates made in Mueller-Hinton Agar (Oxoid); colonies were counted after incubation for $48 \mathrm{~h}$ at $37^{\circ} \mathrm{C}$.

\section{Statistical methods}

Results were expressed as mean and SD. Differences amongst groups were compared by analysis of variance and the Bonferroni method ${ }^{10}$ was used to assess statistical significance at $p \leqslant 0.05$.

\section{Results}

\section{Bacterial adherence to catheters}

The kinetics of adherence of $S$. epidermidis and $E$. coli to the plastic catheters up to $72 \mathrm{~h}$ of incubation are shown in figs. 1 and 2. After incubation for $24 \mathrm{~h}$,

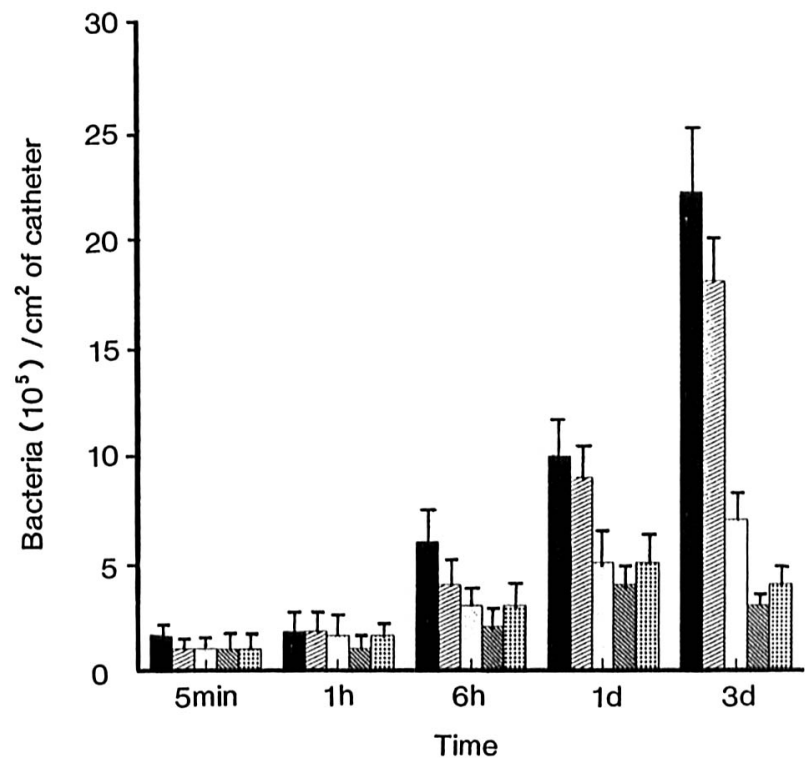

Fig. 1. Mean adherence of $S$. epidermidis to catheters of different materials $(\mathrm{n}=3$; bar $=\mathrm{SD}), \square, \mathrm{PVC} ; \mathrm{Z}$, siliconised latex; $\square$, Teflon $^{\circledR} ; \mathbb{N}$, polyurethane; $:$, Vialon ${ }^{\circledR}$.

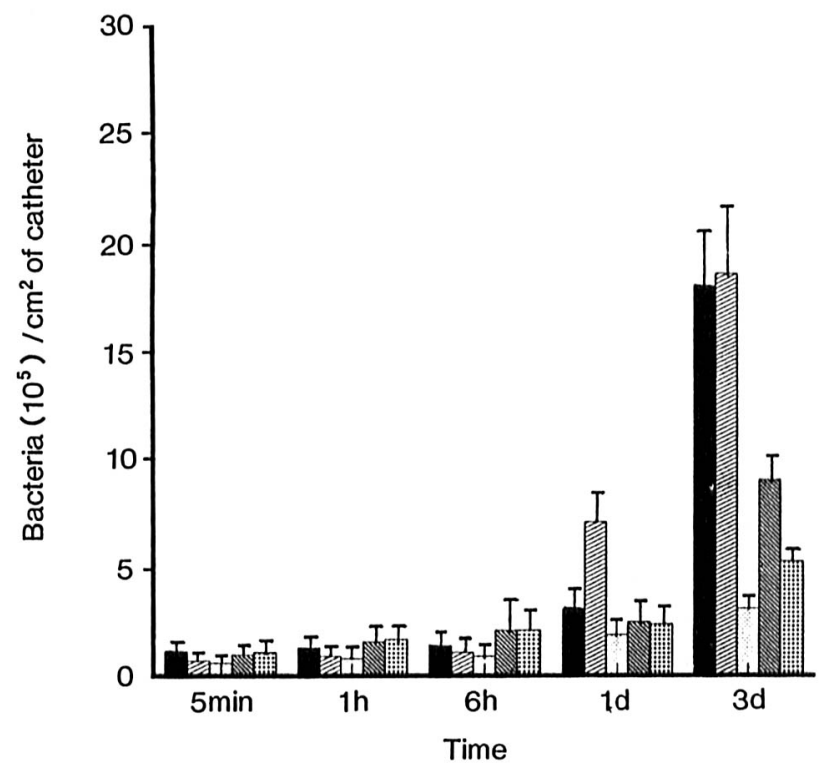

Fig. 2. Mean adherence of $E$. coli to catheters of different material $\left(\mathrm{n}=3\right.$; bar =SD): $\square$, PVC; $\mathbb{Z}$, siliconised latex; $\square$, Teflon ${ }^{\circledR}, \mathbb{N}$, polyurethane; 圈, Vialon ${ }^{\circledR}$.

adherence of both micro-organisms was significantly higher to PVC and siliconised latex than to Teflon ${ }^{\circledR}$, polyurethane or Vialon ${ }^{\circledR}$. Similar behaviour was observed with $S$. aureus and $P$. aeruginosa. The peak of bacterial adherence was reached between 24 and $72 \mathrm{~h}$ for $E$. coli and staphylococci (table I). However, $P$. aeruginos $a$ adhered to the biomaterial more rapidly, reaching maximal adherence between $6 \mathrm{~h}$ for PVC and $24 \mathrm{~h}$ for the other biomaterials.

Maximal bacterial adherence was observed with PVC followed by siliconised latex for $P$. aeruginosa and staphylococci (table I). The adherence of $E$. coli to both biomaterials was similar but was significantly greater than that observed with Teflon ${ }^{\circledR}$, polyurethane and Vialon ${ }^{\circledR}$. The lowest adherence values were 
Table I. Maximum levels of bacterial adherence to five types of plastic catheter during incubation for $72 \mathrm{~h}$ at $37^{\circ} \mathrm{C}$

\begin{tabular}{|c|c|c|c|c|}
\hline \multirow{2}{*}{ Catheter material } & \multicolumn{4}{|c|}{ Mean* (SD) number of adherent bacteria $\left(10^{5} / \mathrm{cm}^{2}\right)$} \\
\hline & S. aureus & S. epidermidis & E. coli & P. aeruginosa \\
\hline Siliconised latex & $26 \cdot 6(3 \cdot 4)$ & $17.9(1.7)$ & $18.6(1.8)$ & $24 \cdot 4(3.0) \dagger$ \\
\hline PVC & $42 \cdot 0(4 \cdot 6)$ & $22.9(2 \cdot 8)$ & $18.5(1.8)$ & $40 \cdot 8(3.8) \ddagger$ \\
\hline Teflon $^{\circledR}$ & $11.4(1.2)$ & $6 \cdot 8(0 \cdot 4)$ & $2.9(0 \cdot 1)$ & $9.8(1.0) \dagger$ \\
\hline Polyurethane & $15 \cdot 1(1 \cdot 4)$ & $3.9(0.6) \dagger$ & $9 \cdot 3(0.5)$ & $13 \cdot 5(1 \cdot 2) \dagger$ \\
\hline Vialon ${ }^{\circledR}$ & $7.5(0.9)$ & $5 \cdot 1(0.3) \dagger$ & $4.5(0.2)$ & $11 \cdot 5(1 \cdot 2) \dagger$ \\
\hline
\end{tabular}

*Mean of three experiments.

$†$ Maximum adherence measured after incubation for $24 \mathrm{~h}$; †after $6 \mathrm{~h}$.

obtained with Teflon ${ }^{\circledR}$ for gram-negative bacteria, polyurethane for $S$. epidermidis and Vialon ${ }^{\circledR}$ for $S$. aureus.

\section{Bacterial growth in catheter eluates}

The growth rates of bacteria in eluates obtained from the incubation of catheter segments in PBS for $24 \mathrm{~h}$ at $37^{\circ} \mathrm{C}$ are shown in tables II and III. After incubation for $24 \mathrm{~h}$, numbers of $E$. coli were significantly higher in PVC, Teflon ${ }^{\circledR}$, polyurethane and Vialon ${ }^{(1)}$ eluates than in the controls. However, in siliconised latex eluates the number of viable organisms was reduced to undetectable levels $(<10 \mathrm{cfu} /$ $\mathrm{ml})$. All the eluates stimulated the growth of $\boldsymbol{P}$. aeruginosa (table II) after incubation for $24 \mathrm{~h}$.

Different results were observed with staphylococci (table III). None of the catheter eluates significantly increased the growth of either $S$. aureus or $S$. epidermidis; only the Teflon $^{\circledR}$ eluate significantly decreased the viable number of $S$. epidermidis after incubation for $24 \mathrm{~h}$.

\section{Discussion}

Bacterial adherence to prosthetic materials can be measured by quantitative culture, ${ }^{11}$ microscopy, ${ }^{12}$ chemiluminescence ${ }^{13}$ or the use of radiolabelled bacteria ${ }^{6}$ The latter method has provided a simple and reproducible method for quantifying the bacterial biomass on the surface of biomaterials. ${ }^{6}$ This method is particularly useful for measuring the initial interactions between bacteria and polymers, which are mainly mediated by attracting and repelling forces such as hydrophobic interactions between the two surfaces. ${ }^{6}$

In our study, adherence was measured over a longer period of time than is usual in such studies. Very little difference in adherence was shown at $1 \mathrm{~h}$ or $6 \mathrm{~h}$, but marked differences developed after $24 \mathrm{~h}$, depending on the strain and the catheter material involved. The increased adherence measured may have been due to microcolony formation and growth may be required for this adherence to occur. However, lack of correlation between longer term adherence and growth in catheter eluates suggests that factors other than growth due to soluble catheter components is involved. Further studies are needed with scanning electronmicroscopy to compare the quantitative data with morphological studies. Observations (unpublished) with different strains of $P$. aeruginosa showed that, at $24 \mathrm{~h}$, bacteria on a PVC catheter are immersed in an amorphous material which is not observed with polyurethane, whereas adherence in this study was similar for both types of catheter material.

Our results indicate that catheter material type may be important in adherence of bacteria to catheter

Table II. Growth of E. coli and P. aeruginosa in eluates from different catheters

\begin{tabular}{|c|c|c|c|c|}
\hline \multirow{3}{*}{ Catheter material } & \multicolumn{4}{|c|}{ Mean (SD) number of cfu $\left(10^{4} / \mathrm{ml}\right)$} \\
\hline & \multicolumn{2}{|c|}{ E. coli } & \multicolumn{2}{|c|}{ P. aeruginosa } \\
\hline & $6 \mathrm{~h}$ & $24 \mathrm{~h}$ & $6 \mathrm{~h}$ & $24 \mathrm{~h}$ \\
\hline $\begin{array}{l}\text { None (control) } \\
\text { Siliconised latex } \\
\text { PVC } \\
\text { Teflon } \\
\text { Polyurethane } \\
\text { Vialon }\end{array}$ & $\begin{array}{l}0.8(0 \cdot 1) \\
\quad 0 \\
1 \cdot 1(0 \cdot 2) \\
1.5(0 \cdot 2) \dagger \\
2.0(0 \cdot 4) \dagger \\
0.6(0 \cdot 2)\end{array}$ & $\begin{array}{c}1 \cdot 5(0 \cdot 6) \\
0 \\
11 \cdot 0(2 \cdot 2) \dagger \\
160 \cdot 0(10 \cdot 3) \dagger \\
250 \cdot 0(19 \cdot 8) \dagger \\
60 \cdot 0(5 \cdot 8) \dagger\end{array}$ & $\begin{array}{l}5.5(1 \cdot 5) \\
7 \cdot 5(1 \cdot 8) \\
6 \cdot 5(1 \cdot 7) \\
7 \cdot 8(2 \cdot 2) \\
7 \cdot 0(2 \cdot 1) \\
6.9(2 \cdot 2)\end{array}$ & $\begin{array}{c}600(31 \cdot 1) \\
1150(111) \dagger \\
3150(320) \dagger \\
2980(262) \dagger \\
3250(342) \dagger \\
3506(298) \dagger\end{array}$ \\
\hline
\end{tabular}

$0=<10 \mathrm{cfu} / \mathrm{ml}$

* Mean of three experiments; initial inoculum $10^{3} \mathrm{cfu} / \mathrm{ml}$.

$+\mathrm{p}<0.05$ compared to the controls. 
Table III. Growth of $S$. epidermidis and $S$. aureus in eluates from different catheter materials

\begin{tabular}{|c|c|c|c|c|}
\hline \multirow{3}{*}{ Catheter material } & \multicolumn{4}{|c|}{ Mean (SD) number of cfu $\left(10^{3} / \mathrm{ml}\right)$} \\
\hline & \multicolumn{2}{|c|}{ S. epidermidis } & \multicolumn{2}{|c|}{ S. aureus } \\
\hline & $6 \mathrm{~h}$ & $24 \mathrm{~h}$ & $6 \mathrm{~h}$ & $24 \mathrm{~h}$ \\
\hline $\begin{array}{l}\text { None (control) } \\
\text { Siliconised latex } \\
\text { PVC } \\
\text { Teflon } \\
\text { Polyurethane } \\
\text { Vialon }^{\circledR}\end{array}$ & $\begin{array}{l}1.0(0 \cdot 3) \\
1 \cdot 0(0 \cdot 4) \\
0.7(0 \cdot 3) \\
0.4(0 \cdot 3) \\
0.7(0 \cdot 3) \\
0.6(0 \cdot 2)\end{array}$ & $\begin{array}{l}0.6(0.3) \\
0.5(0.2) \\
0.2(0.1) \\
0.1(0.06) \dagger \\
0.6(0.2) \\
0.4(0.2)\end{array}$ & $\begin{array}{l}0.6(0.3) \\
0.6(0.2) \\
0.3(0 \cdot 1) \\
0.7(0.3) \\
0.5(0.2) \\
0.5(0.2)\end{array}$ & $\begin{array}{l}0.1(0.04) \\
0.2(0.09) \\
0.2(0.08) \\
0.2(0.08) \\
0.2(0.1) \\
0.2(0.09)\end{array}$ \\
\hline
\end{tabular}

See footnotes to table II.

surfaces. In our assays, polyurethane and Vialon ${ }^{\circledR}$ offered the greatest resistance to adherence of staphylococci and Teflon ${ }^{\circledR}$ for $E$. coli and $P$. aeruginosa. Previous studies ${ }^{11}$ with a blood-agar-roll technique, which measures viable bacteria, have shown that the initial adherence of coagulase-negative staphylococci to PVC catheters was also greater than that observed with Teflon ${ }^{\circledR}$ catheters. The results obtained with single isolates cannot be extrapolated to the whole species because it is known that there is variation between strains of a species both in adherence and in other surface properties.

The measurement of bacterial adherence to clean catheters is a simplification of the events that occur in vivo because the catheters are rapidly coated with different proteins, fluids and cells, but the initial adherence may depend mainly on the catheter biomaterial.

The survival in vitro of coagulase-negative staphylococci adherent to intravascular catheters in the absence of conventional nutrients has been described. ${ }^{7}$ It has been proposed that these micro-organisms could use some of the components of the catheters as nutrients for growth. ${ }^{4}$ It may also be possible that adherence to the surface of foreign objects may allow organisms to become metabolically dormant. ${ }^{7}$ To consider this hypothesis, we tested the effect of catheter components on bacterial growth. We used eluates obtained from the incubation of catheter segments in PBS as growth media. Growth of $E$. coli and $P$. aeruginosa in eluates from PVC, Teflon ${ }^{\circledR}$ and both polyurethanes was significantly greater than that observed in the controls. However, siliconised latex eluate was toxic for $E$. coli but increased the growth of $P$. aeruginosa. None of the eluates tested increased the growth of either $S$. aureus or $S$. epidermidis. Staphylococci have complex nutritional requirements and it seems less likely that they would grow in a catheter eluate in PBS. Many biomaterials, e.g., PVC, contain several additives to make them flexible enough to be used in catheters. Others, e.g., siliconised latex, come from different tropical countries; in the manufacturing process, several chemicals are used and the exact formulae are unknown. Some of these substances could be eluted from the catheter into the medium and could be used by different micro-organisms.

Although these findings require further characterisation by more extensive in-vitro and clinical investigation to define the mechanisms involved in the pathogenesis of catheter-related infections, these preliminary data suggest that the effect of new biomaterials on bacterial adherence and viability should be evaluated before clinical trials to obtain catheters that could prevent bacterial adherence and colonisation.

This study was partly supported by grant no. PA 85-0299 from the Dirección General de Investigación Científica y Técnica (DGICYT, Spain). We thank M. C. Guzman for her technical assistance and Sandra Hidalgo for assistance with the preparation of the manuscript.

\section{References}

1. Cleri DJ, Corrado ML, Seligman SJ. Quantitative culture of intravenous catheters and other intravascular inserts. $J$ Infect Dis 1980; $141:$ 781-787.

2. Maki DG, Goldman DA, Rhame FS. Infection control in intravenous therapy. Ann Intern Med 1973; 79: 867-887.

3. Maki DG. Nosocomial bacteriemia: an epidemiologic overview. Am J Med 1981; 70: 719-732.

4. Peters G, Locci R, Pulverer G. Adherence and growth of coagulase-negative staphylococci on surfaces of intravenous catheters. $J$ Infect Dis $1982 ; 146:$ 479-482.
5. Welch GW, McKeel DW, Silverstein P, Walker HL. The role of catheter composition in the development of thrombophlebitis. Surg Gyn Obstet 1974; 138: 421-424.

6. Pascual A, Fleer A, Westerdaal NAC, Verhoef J. Modulation of adherence of coagulase-negative staphylococci to Teflon catheters in vitro. Eur J Clin Microbiol 1986; 5: 518-522.

7. Franson TR, Sheth NK, Menon L, Sohnle PG. Persistent in vitro survival of coagulase-negative staphylococci adherent to intravascular catheters in the absence of conventional nutrients. J Clin Microbiol 1986; 24 : 559-561.

8. Verhoef J, Peterson PK, Quie PG. Kinetics of staphylococci opsonization, attachment, ingestion and killing by human polymorphonuclear leukocytes: a quantitative assay using 
$\left({ }^{3} \mathrm{H}\right)$-thymidine labelled bacteria. J Immunol Methods 1977 ; $14: 303-310$.

9. Ashkenazi S, Mirelman D. Adherence of bacteria to pediatric intravenous catheters and needles and its relation to phlebitis in animals. Pediatr Res $1984 ; 18$ : 1361-1366.

10. Wallenstein S, Zucker CL, Fleiss JL. Some statistical methods used in circulation research. Circ Res 1980; 47: 1-9.

11. Sheth NK, Rose HD, Franson TR, Buckmire FLA, Sohnle PG.
In vitro quantitative adherence of bacteria to intravascular catheters. J Surg Res 1983; 34: 213-218.

12. Hogt AH, Dankert J, Hulstaert CE, Feijen J. Cell surface characteristics of coagulase-negative staphylococci and their adherence to fluorinated poly (ethylenepropylene). Infect Immun 1986; 51 : 294-301.

13. Kristinsson KG. Adherence of staphylococci to intravascular catheters. J Med Microbiol 1989; 28: 249-257. 
